\title{
Faith community as a centre of liberationist praxis in the city
}

\begin{abstract}
Author:
Elina Hankela ${ }^{1,2}$

Affiliations:

${ }^{1}$ Research Institute for

Theology and Religion,

University of South Africa,

South Africa

${ }^{2}$ Department of Theology, University of Helsinki,

Finland

Note:

This article forms part of the special collection on

'Doing urban public theology in South Africa: Visions, approaches, themes and practices towards a new agenda' in HTS Teologiese Studies/Theological Studies Volume 70, Issue 3, 2014. The collection is the result of the project 'Urban Public Theology', which was initiated by the Institute for Urban Ministry but later expanded to include several academic departments and institutes at the University of Pretoria (UP) and University of South Africa (UNISA).

The leading centres in this regard were the Centre for Contextual Ministry (UP) and the Research Institute for Theology and Religion (UNISA).
\end{abstract}

Correspondence to:

Elina Hankela

Email:

elina.hankela@gmail.com

Postal address:

PO Box 392, University of

South Africa, Pretoria 0003,

South Africa

Dates:

Received: 17 June 2014

Accepted: 04 Aug. 2014

Published: 20 Nov. 2014

Read online:
Theologians speak of the silence of churches' prophetic voice in the 'new' South Africa, whilst the country features amongst the socio-economically most unequal countries in the world, and the urban areas in particular continue to be characterised by segregation. In this context I ask: where is liberation theology? I spell out my reading of some of the recent voices in the liberationist discourse. In dialogue with these scholars I, firstly, argue for the faith community to be made a conscious centre of liberationist debates and praxis. Secondly, I do this by suggesting two theoretical building blocks (i.e. critical deconstruction and radical friendship) for local faith communities that wish to grow in a liberationist fashion.

\section{Introduction}

James Cone (2013:xv) writes, ' $[t]$ his black religious experience, with all its tragedy and hope, was the reality in which I was born and raised'. The contradiction between tragedy and hope that Cone grappled with, together with his community, was not the least ignited by the hypocrisy and plain cruelty of white Christianity that 'either openly supported slavery, segregation, and lynching as the will of God or ... was silent about these evils' (Cone 2013:131). Speaking to the reality of racism and white supremacy, he quotes James Baldwin's prophetic and polemic words from 1963:

[Life] forces you, in any extremity, any extreme, to discover what you really live by, whereas most Americans have been for so long, so safe and so sleepy, that they don't any longer have any real sense of

what they live by. I think they really think it may be Coca-Cola. (Baldwin quoted in Cone 2013:54)

The conflict that Cone describes, both personal and structural, rising from an experience of the hypocrisy of people of faith vis-à-vis real tangible suffering, and from the Christian majority's complacency with a dehumanising status quo, either active or passive, continues to be lived and felt around the world. South African theologians have in the recent years raised a concern about the silence of the prophetic voice in the country at different stages of the new dispensation (Le Bruyns 2012; Maluleke 2000; Motlhabi 2009; Storey 2004), about a lack of theologians' involvement with or liberation theologies' meaning for people's struggles (Buffel 2010; Mosala 1989; Pityana 1994), and about the poor having been lost as interlocutors in democratic South Africa, also in the discourse of the church (Vellem 2012).

Reading these scholars in a cosy coffee shop in the middle-class suburb of Melville in Johannesburg, the economic hub of one of the socio-economically most unequal countries of the world, one is bound to ask with Baldwin: what do faith communities live by? I have found a coffee shop, managed by an Algerian national, where all races comfortably claim the space - not a given in Johannesburg - and where academics sit next to young entrepreneurs, musicians and business consultants. But the Zimbabwean craftsman, who sells crafts in Melville and knows many of us, hardly ever enters the shop; I chat with him on the street. More so, when I drive out of the suburb I face the same young man day by day at the traffic lights down the road, asking for money. He is not an anomaly, or an abomination, but an integral part of the normal of Johannesburg and the world; he is part of the 'global order' that 'leaves the poorest to die', 'part of the normal working of society itself' (Petrella 2008:247).

Since the early 1990s, integration has been a central concept in South African urban spatial planning, but urban areas (which accommodate $71 \%$ of the population) ${ }^{1}$ continue to be characterised by unequal structures, such as uneven access to economic opportunities (Du Plessis 2014). Whilst racial segregation has long been a characteristic of South African cities as a result of industrialisation, segregation and apartheid eras, today some speak of 'new segregation' referring

1.Du Plessis bases the percentage on the National Urban Development Framework: Working Draft (10 June 2009) for Consultation (Department of Cooperative Governance and Traditional Affairs and The Presidency).

How to cite this article: Hankela, E, 2014 'Faith community as a centre of liberationist praxis in the city', HTS Teologiese Studies/ Theological Studies 70(3), Art. \#2768, 9 pages http://dx.doi.org/10.4102/hts.v70i3.2768

Copyright: @ 2014. The Authors. Licensee: AOSIS OpenJournals. This work is licensed under the Creative Commons Attribution License. 
to a shift from race to class as the basis of residential segregation - whilst the two remain strongly interlinked and from state to market as the regulating party (Hamann \& Horn 2014).

Despite the segregation, in some way the worlds of the wealthy and poor, black and white, or citizen and foreign national are extremely - uncomfortably, some may say - close to each other in South African cities. In the 1990s, expanding townships and informal settlements reached onto the borders of white suburbs. Racial desegregation was faster in inner cities than within white suburban spaces themselves. But inner cities also began to undergo resegregation (Hamann \& Horn 2014) ${ }^{2}$. Inner cities and the inner city of Johannesburg in particular have also been a key destination to migrants from the continent since the 1990s and have become known for xenophobia towards the black African other (Landau 2007).

A majority (74\%) of those reshaping and struggling with the different forms of segregation and exclusion in South Africa adhere to Christianity (Census 2001 referenced in Chipkin \& Leatt 2011) $)^{3}$. Maybe amongst church members also in South African cities - the group that struggles with the conflict between what is preached on Sunday mornings and what happens in society at social, economic and political levels is a minority, as Charles Villa-Vicencio (2014) argues, much in line with what Cone writes, despite writing in a different geographical and social location. The group might, as Villa-Vicencio maintains, moreover be often side-lined in the politics of their churches in a church that 'has long had a split personality, consisting of traditional believers who cling to institutionalized ritual and what they regard as doctrinal purity and activists whose faith prioritizes social action' (Villa-Vicencio 2014).

\section{The question about the faith community}

These contradictions set the direction for this article. Fundamentally, my concern is not so much the split personality of the church, but the seeming minority nature of the liberationist split. A radical liberationist model does not seem to structure our faith communities, and consequently is not a force of radical social change.

I approach the matter through spelling out my reading of some of the recent voices in the liberationist discourse. I begin by engaging with Ivan Petrella's polemic on the state of liberation theologies (in the Americas, and especially North America), and a need for this discourse to rebel against itself. Inspired by Petrella, but opting for a different direction, I suggest that liberation theologies reverse the threat, or reality if you wish, of being an elitist enterprise by making the faith community a conscious centre of liberation theological debates. I then turn to some liberationist building blocks (i.e. critical deconstruction and radical friendship)

2.Resegregation refers to $80 \%-100 \%$ of a population group having been replaced by another or others.

3.The 2011 Census did not involve statistics on religion. for local faith communities. When reading the writings of the scholars with whom I engage in this article, I looked for ways of answering the following question in particular: How could the structural and (inter)personal levels of experience be negotiated in the context of a complex local community in a way that a liberationist approach could be owned by the community, and by representatives of various social locations (be it citizen or foreign national, wealthy or poor, black or white, male or female, one ethnicity over another, etc.)?

The question is located on the interface between personal and structural experience. Structural analysis, the acknowledgement of the power embedded in various humanmade systems and the determination to address systemic change were the crucial new emphasis that liberation theologies brought into the theological discourse in the 1970s. Today scholars across the liberationist board continue to address the link between personal and structural experience. In the introduction to The reemergence of liberation theologies, which as a whole restates the continuing importance of theologies of liberation, Thia Cooper (2013:1) writes of the liberationist approach as one according to which sin 'exists in structures and in individuals'. Paul Farmer's - who uses liberation theology and the work of Gustavo Gutiérrez in particular in his work as a medical anthropologist, and a medical doctor - insistence on us living in 'one world' (Farmer 2013a:19) also underlines the organic relationship between the person and the structure:

$[I] \mathrm{t}$ is important that we resist looking away from social suffering and pretending that the world's poorest do live in a country of their own, a nation hidden away from view so that its suffering and sickness and strife might not trouble those who live in the country of the healthy and prosperous. (Farmer 2013b:135)

As persons we share in the same world that is structured to benefit some at the expense of others. 'Social suffering' here refers to the reality of 'those marginalized by poverty, racism, gender inequality, or a toxic admixture of these and other forces and events, including war and slavery and political violence' (Farmer 2013b:100). Cone's (2013:153) describing of 'social suffering' as something 'which comes from human hate' further highlights the connection between the personal and structural.

Whilst the question about a liberationist faith community is global and the scholars I engage with come from different contexts, I ask the question as a white foreign female in the context of Johannesburg and the Central Methodist Mission $(\mathrm{CMM})$ in its inner city that was part of my life for years as the location of my doctoral research, and where I continue to worship and volunteer. This article is not based on empirical research, but my empirical research (cf. Hankela 2013, 2014a, 2014b) and experience in a particular context continue to form my thinking and questions. Hence I want to say a few words about my physical location before taking on the question itself.

The Johannesburg inner city has been impacted on by capital flight to the northern suburbs since the late 1970s, and increasingly so in the 1990s (Murray 2011:87). Twelve per 
cent of people in the inner city earn a minimum of R1500.00 per month; $35 \%$ or more are officially unemployed. More than a quarter million people live 'without substantive public sector investment in new social services (including investment in schools and health care facilities) and with poorly maintained urban infrastructure despite ongoing regeneration initiatives' (Winkler 2013:319). In the 1990s, in order to counter the impact of the capital flight, the public sector began the inner-city 'regeneration' project, aiming at 'beauty' (using public funds towards revamping the physical space, for instance, by funding art installations) and, maybe more importantly, at economic growth (through attracting private investment). The resurgence attempts have been shaped in the logic of a free-market model, and have hence necessitated public-private partnerships that favour the market and measures that aim to control the area that is often viewed as a space 'deemed to be chaotic, hyper-fluid and "dysfunctional"' (Winkler 2013:310-311, 314; the directly quoted part referring in particular to Hillbrow).

In the inner city, the CMM is known for having sheltered thousands of foreign nationals in and around its precincts, largely due to the liberationist vision of its leader, Rev. Dr Paul Verryn. Whilst the ministry also responds to the immediate needs of poor people by offering shelter and aims to encourage people to run for themselves, for instance, through providing skills training programmes, Verryn described the prophetic aspect of the ministry with the metaphor of 'a thorn':

I think that it [the dwellers' presence at the CMM] says to the inner city that poverty is definitely one of our major priorities and that we will not keep quiet until there is humanity for all. (quoted in Hankela 2014a:148, 165; also see Hankela 2014b)

The God who inspires this vision has nothing in common with the one people recreate in an image that embarks 'no confrontation with reality of the world' (quoted in Hankela 2014a:148, 165; also see Hankela 2014b) ${ }^{4}$.

As the leader of the CMM, Verryn has, on the contrary, impacted on the church space in a way that has not only stood as a confrontation in society but also within the church. Fieldwork that I conducted at the CMM in 2009 suggested that many congregants did not have a sense of ownership in regard to the ministry that had revamped the church, and many were clearly uncomfortable with the lack of cleanliness, the deteriorating state of the building or what they experienced as disrespect from the side of the people staying in the church. I was told that a number of worshippers had left the CMM to join other churches (cf. Hankela 2013, 2014a).

Whether one agrees or disagrees with this particular implementation of a liberationist vision, one has to agree that it is easy to find a church in which the structural critique of society does not incarnate in the everyday life of the church. Where then is liberation theology?

4. Interview conducted with Paul Verryn by author in Johannesburg on 02 December 2009.

\section{Liberation theology: Between an academic guild and the faith community}

At the end of Beyond liberation theology: A polemic, Ivan Petrella (2008) asks a brave question:

To work in liberation theology today could mean to work outside of it, by finding ways the epistemological and practicalmoral elements can infiltrate, subvert, and transform other bodies of knowledge. Here the liberation theologian need not carry the label of 'theologian' and works best under a different disciplinary guise. Could the future of liberation call for the dissolution of liberation theology as an identifiable field of production? (loc. 4448)

Petrella's question is raised on the basis of his analysis of the state of the world and that of liberation theology, particularly in the context of the Americas. He (2008:3412) writes of liberation theology having been 'co-opted into mainstream theological discourse', a matter that has been addressed by Vuyani Vellem (2012) in the South African theological context. Whilst comfortable in the academia and enjoying 'bourgeois respectability', Petrella (2008:3412) argues, liberationist discourses find themselves 'at the margins of politics' without a social movement with a potential to mobilise 'a liberation theology that comfortably exists in the academy is one that will rarely pose a threat to the status quo'. Thus liberation theology is under threat of being or becoming 'a theology for the middle class' and 'just a kind of writing' (Petrella 2008:3509). Vellem's (2012:348-351) argument about the South African situation is parallel: the concept of preferential option for the poor has been embraced by various theological schools but the way in which it is used does not reflect a liberationist understanding.

Petrella (2008), furthermore, quotes Emilie Townes who speaks of liberation theologians as arrogant ships passing in the night:

It is as though we in the academy and we in the church are ships passing in the night and we are not even looking for one another. Our continued arrogance and hoarding of our meagre privileges must stop, or we need to find another name for ourselves because we have ceased being Christian. (loc. 3483)

As academic theologians, one must note though, liberationists meet with each other and strengthen formal and informal networks at conferences, and dialogue with one another in journal articles and books. But if the liberationist movement is mainly confined in the academia, the protest is also under threat of turning into academic chatter. Again echoing a similar discomfort, Olahile Buffel (2010:477) states that in South Africa Black theology 'became a monopoly of educated black Christians'. Together Petrella, Vellem, Townes and Buffel raise a critical concern about the dilution of struggle and commitment in university corridors. Moreover, their critique questions the existence of a vital organic connection with faith communities. And so Petrella (2008) calls for rebellion: 
Liberation theologies were born of rebellion ... To make these questions [related to whether liberation theology has become just a kind of writing] disappear liberation theology must once again rebel; this time, however, it must rebel against itself. (loc. 3509)

I read Petrella from the perspective of a lack of - maybe also a social movement as he argues but, I think, more importantly - faith communities that reflect a liberationist interpretation of the gospel. Thus I ask, in what ways liberation theologies could promote new (or old) ways of engaging communities, for the sake of a viable future and in order not to turn into an elitist enterprise and a kind of writing.

The unique opportunity that a Christian social activist or theologian has in a struggle for social justice alongside with others from so-called secular or other faith backgrounds is the link to the Christian faith community. Development studies scholars, who have in the recent years become increasingly interested in the role of faith-based organisations in development, have noted the rootedness of faithbased organisations in local communities, and some have argued that this connection provides them with an edge in development work (cf. Clarke \& Jennings 2008; Moyer, Sinclair \& Spaling 2012). In South Africa churches have been said to represent and mobilise more people than other civil society actors or organisations, from all walks of life (Krige 2008:17).

In order for this mobilisation to be liberationist and prophetic, I believe that liberation theology qua theology still has a place - if its focus is on the community of believers for the sake of mobilising it. Benjamín Valentín (2013:53) writes about 'our writings' being 'more like prolegomena to theology' and 'lament[s] the kind of theological evasion that has surfaced among us'. In other words, he calls us to write theology again, and I would like to add, to write theology that has a potential to transform faith communities where people come (amongst other reasons) to look for spiritual and theological guidance.

If liberation theology would (again) be a theology of and for communities, skills in economics, politics and so on - which Petrella (2008:3750-3816) rightly calls liberation theologians to embrace - could be found in those communities. To make use of the tools of social sciences, one could walk into faith communities and find an economist, a political scientist, a cleaner, a business owner, a domestic worker, an unemployed person and a mayor amongst the people. Likewise people who have direct and constant access to places inside and outside academia, which Petrella calls liberation theologians to take on (as reflected in the question quoted above, and again I agree with him), could be found in the pews on Sundays.

Yet the focus on faith communities does not only stem from a practical-moral motivation. The liberationist tradition supports the task to think of liberation, not only as a movement of the marginalised, let alone theologians, but as the calling for the church as a whole to a life of ongoing conversion. Liberation theology took off as an organic part of people's struggle in the 1960s and 1970s, or at least that is what literature tells us who were born after liberation theology. Gutiérrez (2013b:77) states in 1984 that 'this way of solidarity is not to be undertaken by isolated individuals. It should be done along with the entire church'. In 2009 he still calls for 'personal and ecclesial conversion' (2013c:150). Curtiss Paul DeYoung (2012:79-85) writes about Christian congregations of the 1st century, which consisted of both colonised people and beneficiaries of that very colonisation, yet importantly, being led by the former. The 1st century church was 'building an international anti-imperial movement of an alternative society based in local communities' (Richard Horsley quoted in DeYoung 2012:85): it 'might not recognize much of what we call church in twenty-first century' (p. 86). Traditionally liberation theology does not belong to academics, or even to social movements, but also and importantly to the complex and heterogeneous local Christian communities (i.e. the majority of Christians).

In the rest of the article I begin to think what making faith communities a centre for liberationist debates could look like: I do this by looking at two notions that could support the nurturing of liberationist faith communities in a city like Johannesburg.

\section{Towards a liberationist community 1: Critical deconstruction}

Elina Vuola (2003:106) argues that liberationists could benefit from listening to selected interpretations of postmodernism, a vanguard of deconstruction, in order to sharpen their own discourse, so that the praxis starting point and the option for the poor be taken more seriously than has actually been done'. The initiator of her suggestion is the male-centredness that she argues had been characteristic of Latin American liberation theology and the consequent exclusion of the voice of poor women: 'The postmodern challenge at its best asks to look at the relativity of different subject positions with the critical eyes of "yet another other"' (Vuola 2003:105).

Vuola notes that postmodernism could be criticised as a Western enterprise, which parades individualism and the end of metanarratives, and, consequently, silences voices from outside the West, stamping them as partial and lacking in universal meaning. However, postmodernist texts - that emphasise the impact of social location on thinking and action - have also been used to critically reread modernity in the global South, in ways that, at least in theory, allow space for different voices (Vuola 2003:106-107). This is, of course, not new to liberation theology, but as Vuola (2003:112) suggests, an explicit and critical engagement with postmodernist premises may help in critically analysing the liberationist tradition, and explicitly (re)conceptualising the margins: ' $[I] \mathrm{t}$ means that one should always be willing to look at one's own truth-claims and positions with the critical eyes of others'.

In other words, what Vuola does methodologically - in order to include the voice of poor women in the discourse 
and praxis - is to destabilise (even if not do away with) the (static) dichotomies that the liberationist discourse has often assumed as a starting point. She emphasises that, as 'an ambiguous legacy', postmodernism ought to be neither discarded nor embraced uncritically by liberationists (Vuola 2003:105). Indeed, such deconstruction is a dangerous task as it could lead to the relativisation of suffering and the melting of structural critique into a bourgeois kind of writing, or a kind of playing church, with no sense of commitment and urgency. As some feminist scholars have pointed out, it could lead to she disappearing into he (or Africa into Europe, black into white, poor into wealthy, refugee into citizen) in a world that claims to have no epistemological preference (Vuola 2003:108). Yet Vuola manages to convince the reader, or me, about the potential of such destabilisation for the sake of a deeper understanding of and a more thorough praxis based on the preferential option: for the sake of remaining credible in a world that does not fit neat abstractions.

To an extent such reconceptualising and deconstruction of certain liberationist positions can be seen at work in the emergence of intersectional liberationist paradigms, and in the suggestion - almost a plea - made by different liberationists (such as Townes) for representatives of various schools of liberation theology to seek each other in the spirit of solidarity. For instance, in South Africa some Black theologians could in the 1980s justifiably argue for the necessity of sticking to race as the core category of struggle and not diluting the edge of race analysis with class critique (e.g. Sedibi 1986); today no liberationist in the country can credibly bypass socioeconomic class as a key component in struggle for liberation, and courtesy of the work of the Circle of Concerned African Women Theologians gender, too, is a visible factor in the liberationist conversation. These developments call for a continuing conversion: the black lesbian theologian, if part of what could be called an intellectual middle class, must listen to 'yet another other' (cf. Vuola 2003:105); the Zimbabwean Shona-speaking professor cannot claim to share the social location of her or his compatriots who experience xenophobia in the 'piece job' market; let me not even go to the white Finnish female theologian having to push her intellectual and emotional frameworks in order to hear the young Zimbabwean girl's truth in the Jabavu township.

What I want to suggest at a level of a local community follows from the intersectional trend and Vuola's insight, even if taking a different direction: critical deconstruction of liberationist dichotomies in the context of local faith communities could allow more space for personal, and consequently also ecclesial, conversion. In practice, critical deconstruction at the personal level means emphasising dialogue (i.e. a mutual learning process) at the expense of a predetermined preferential option when engaging the members of a faith community. Following the rationale of Mercy Amba Oduyoye's (2001:17) interpretation of African Women's theology as 'a theology of relations' the dialogue would opt - at the interpersonal level - for mutuality at the expense of hierarchies; yet not at the expense of submitting to existing structural hierarchies, but aiming at the wellbeing of everyone. Aiming at the well-being of everyone turns the gaze to the marginalised without excluding the privileged from the dialogue. As dialogue partners, persons are then not treated as structures (i.e. being as essentialist, static or predetermined), even if the ways in which structures impact on their lives and in which they impact on the re/ deconstruction of structures are acknowledged and scrutinised (i.e. being as active, undetermined).

At its best, epistemological deconstruction at the interpersonal level would place responsibility and agency on representatives of every social location. This is crucial in the context of faith communities in cities like Johannesburg that are characterised by stark structural inequalities and consequent segregation (be it socioeconomic, racist, patriarchal, homophobic or xenophobic) but also by the proximity of people who occupy different social locations and belong on different sides of various symbolic and physical boundaries.

Such deconstruction, of course, bears the threat of turning the church into a liberal feel-good space. The early Cone $(1997 / 1969)$ is right:

The liberal, then, is one who sees 'both sides' of the issue and shies away from 'extremism' in any form. He wants to change the heart of the racist without ceasing to be his friend; he wants progress without conflict ... Blacks do not want his patronizing, condescending words of sympathy. They do not need his concern, his 'love,' his money. It is that which dehumanizes; it is that which enslaves. (Cone 1997:27-28)

The aim of opening space for dialogue, which allows a voice to every person, is not to avoid conflicts; the goal is rather to create conflicts within people. The conflicts that arise are particularly uncomfortable for the structurally privileged persons who are faced by a quest to make a personal choice to listen to the marginalised, to feel their pain and to take a stand for structural, social justice. Nigel Oakley (2004:453), who writes about the adaptability of the Freirean model in middle-class faith settings in Britain, emphasises dialogue, instead of paternalism, as the Freirean principle: fighting 'alongside' instead of 'for' the poor (p. 448). The aim is not to create social cohesion at the expense of leaving the status quo untouched:

$[U]$ ntil sharp political questions start to be asked, there will be no real progress, no real debate, and the voices of the marginalized will still not be heard - not least by the middle-class Christians who desperately need to hear [them]. (Oakley 2004:462-463)

Hence, in a space of critical deconstruction, the uncomfortable questions are directed both down and up the societal ladder. Gutiérrez (2013a) describes the starting point for liberation theology by a question:

I do theology as one who comes from a context of deep poverty, and thus for me, the first question of theology is how do we say to the poor: God loves you? ... This is the question that the theology of liberation attempts to answer. (pp. 27-28) 
The formulation implies that social class plays a critical role in whether, and how, one can experience 'love'. Yet 'love' that materialises in the form of oneself driving a BMW whilst the next person sleeps at the street corner just off ones garage door and does not have access to health care because his or her identification document was stolen does not reflect agape either. If we agree with Gutiérrez, in a city like Johannesburg, it is necessary to simultaneously ask how to say to the rich what it means that God loves them:

Studying 'up' as well as 'down' would lead us to many 'common sense' questions in reverse. Instead of asking why some people are poor, we would ask why other people are so affluent. (Laura Nadar quoted in Petrella 2008:3875)

The double-direction of the question rises from the need to conscientise the whole faith community (Freire 2000). Such questions aim at giving both privileged and unprivileged individuals an opportunity to recognise their embeddedness in oppressive structures, but also to allow each individual a personal choice. Asking the same questions in both directions places a faith community in one world - and the people in one faith community. In such spaces of conflict, the poor stop being the target of the process, an end of an ethic. The target is as much (maybe more) those who benefit from societal structures.

Lastly, as Gutiérrez (2013c:156-157) argues, in a liberationist community poor or marginalised individuals too must enter the road of conversion to the option for the marginalised. Allan Boesak (2012) highlights this requirement through rereading the struggle of Rizpah (2 Sm 21-24):

She never once calls attention to herself despite the right her history gives her, but she rises above the temptation of victimhood to stand in solidarity with others. Her righteous anger is not out of pity for herself but because of the injustice done to others and the danger it poses to the soul of her people. (p. 38)

Rizpah chooses solidarity. Hers is an option for the marginalised as a structural reality; it is not for the lifting of an individual poor person to a class of BMW owners nor is it not an option to make life easier for oneself.

\section{Critical deconstruction in inner-city Johannesburg}

The CMM offers a setting to think of what critical deconstruction at personal level could mean in a local community. The church building is occupied by a large number of mainly poor Zimbabwean migrants. The presence of the people in the church surfaces as a political statement that chooses the side of structurally marginalised persons. Inside the church building the statement has raised resentment amongst the congregation: the presence of the people has come with grime and crime. Here listening to both sides of the story does not (necessarily) amount to letting go of a liberationist stream (cf. Hankela 2014a).

Listening to persons, to 'an irreverent cacophony of voices and unique ideas' (Medina 2013:84) from across different social and structural boundaries, would mean that the asylum seekers - or the poor or women, or the poor female asylum seeker - cannot alone have the truth of what takes place at a location like the CMM. One does need to listen to a migrant who feels that congregants hate them and feels violated when a congregant moves to sit further away from him or her in the pew. One also needs to listen to a congregant who feels that the church and its members are being disrespected because of what appears to him or her as conscious vandalism by those staying in the church (see Hankela 2014a, 2013 on the different voices at the CMM).

Dialogue, which places responsibility (but also agency) on both parties, has the potential of mutual learning that can ultimately illuminate oppressive structures in society, and the one origin of the suffering of the marginalised and what is experienced as suffering by those better off in a given context. For instance, at the CMM the broader political and socioeconomic situation impacts on the condition of the church building. Because this community exists in one world of (structural) conflicts the ultimate aim of deconstructing the predetermined liberationist positions inside the church is to create space for the community to realise the interrelatedness of personal and structural experience and take a stand.

Moreover, in an inner-city community like that of the CMM the usefulness of critical deconstruction is further supported by the fact that drawing static lines between privileged and unprivileged persons is not straightforward: at the CMM the migrants were admittedly in a structurally marginalised situation (asylum seekers, foreign nationals, black, poor) but, on the other hand, the congregation, too, was predominantly black and amongst them were members who were not necessarily socio-economically much better off than some of the people staying in the church (cf. Hankela 2014a).

In other words, I want to speak particularly to the situation of a city church that within herself, or amongst the sister societies or congregations in the city, include a variety of social locations - citizen and foreign national, male and female, poor and wealthy, Xhosa and Sotho, maybe even black and white. The space to express every experience should then not lead to a patronising approach to helping the poor, 'loving' the black or tolerating the female but to a deeper understanding of the structures through various experiences. When the pool of experiences is used to reconstruct an understanding of the systems against which individuals and faith communities are to unite, a bias for the wholeness of human experience will opt for the marginalised at the structural level. The poor person and the wealthy person, the citizen and the foreign national, the male and the female, the heterosexual person and the LGTBI person are then all called to convert to the option for the marginalised.

Critical deconstruction goes hand in hand with radical friendship that enables the representatives of different social locations, not only the minister or lay leader, to listen to the experience of the other. 


\section{Towards a liberationist community 2: Radical friendship}

In the edited volume In the company of the poor, Gutiérrez and Farmer speak of friendship and accompaniment as a crucial aspect of a liberationist approach. Gutiérrez (2013b / 1984) writes:

It is a work of concrete, authentic love for the poor that is not possible apart from a certain integration into their world and not possible apart from bonds of real friendship with those who suffer despoliation and injustice ... True love exists only among equals. (Gutiérrez 2013b:81)

In Gutiérrez' thinking the starting point is the preferential option for the poor, and consequently, the emphasis is on one's access to the experience of the poor. Integration between different social locations should happen into their world, contrary to the common silent, default assumption that the poor should integrate into the world of the well-heeled. This temptation of the privileged to see their location in the world as the norm, and consequently invite the other to be part of that world, is also acknowledged by DeYoung (2012):

Today white congregations [in the United States] invite persons of color into privilege rather than asking whites to discard racial privileges and join with persons of color. Reconciliation in multicultural congregations is often defined by external realities such as suburban locations, white origins, and society's racialization rather than by biblical witness. (p. 86)

DeYoung speaks in the context of the United States and of race, but the comment illuminates the broader logic of structural power relations in a local church context: there is no reason to imagine that those in a privileged position in society and churches (i.e. white, male, heterosexual, citizen middle class, etc.) would either be conscious of their privilege or volunteer to let go of it (cf. Petrella 2008:2851 on 'naiveté').

Gutiérrez' strategic reversal of the order of integration highlights the liberationist concern with social justice instead of (only) social cohesion. The reversal also surfaces as a requirement for real friendship and authentic dialogue between and across people's different realities. In line with this reversal, Freire's (quoted in Petrella 2008:3663) note that the " primary concern" of Third World theologians is ... to soak themselves in the Third World' can also be applied to faith communities. The poor in many ways already share, or are soaked, in the world of the wealthy (just as women share in the world of men, and so on), be it via television shows and adverts or through the eyes of domestic workers. This is why it is for the privileged, in particular, that 'this option involves a commitment that implies leaving the road one is on' in order to enter 'the world ... of the one excluded from dominant social sectors, communities, viewpoints, and ideas' (Gutiérrez 2013c:148).

Farmer (2013b:128-129) emphasises societal structures as a source for the difficulty of leaving the world of privilege and walking alongside the marginalised: as 'part of the spirituality of accompaniment', tangible physical proximity with those from different social locations is not only missing in many societies but could be a method for change: 'Physical and social proximity is important to accompaniment, but uncommon in a country segregated by race or class or both.'

Gutiérrez and Farmer's emphasis on friendship and proximity is echoed in DeYoung and Cone's writing as well. DeYoung (2012:87-88) speaks of reconciliation as exchanging places with the other and of the importance of intimacy for radical reconciliation between people groups, instead of simply 'attending diverse Sunday services without actually engaging in deep intimate relationships where you are transformed by the other person's reality'. Again personal relationships and proximity across social boundaries surface as a route towards structural change. Cone, for his part, speaks of the heart and feeling as integral parts of a liberationist approach. In his critique of Reinhold Niehbuhr's lack of willingness and/or ability to give central attention to white supremacy in his theological and ethical writings, Cone (2013:41) writes that 'Niehbuhr had "eyes to see" black suffering, but I believe he lacked the "heart to feel" it as his own'. Cone (2013:52) then contrasts the lack of real relationships between Niehbuhr and African Americans to Dietrich Bonhoeffer's personal connection with the black community during his stay in the United States: 'Niehbuhr made no effort to engage in dialogue with black religious leaders and scholars or to develop friendship with black people with whom he could learn about race.'

Yet despite the preferential option, 'real friendship', 'intimate relationships', 'dialogue' and 'proximity' imply the importance of both parties in the relationship. All these notions convey a strong sense of mutuality and reciprocity. In the early church, too, Jews, the societal underdog, led the Christian communities but Greeks were also embraced by these communities (DeYoung 2012:79-85). The reversal of the order of integration appears as a means to achieve a place where love can exist 'among equals'. To imagine that only the privileged need proximity or benefit from friendship with the other, on the contrary, would easily lead to the unprivileged person being denied agency as a (fallible) human being.

Finally, forging space for radical friendship is not aimed at individuals from different social locations liking each other. Friendship as 'I like you and you like me' in a local faith community is a nice thing but not the aim. Perfect Hlongwane (2013) aptly describes the inadequacy of such warm feelings in Jozi: A novel through one of the characters discussing the concept of race and its implications in Johannesburg:

$[N] \mathrm{o}$ country in the world needs frank and open discussion about race relations more than this one does. What happened since the hand of reconciliation was offered by the oppressed natives? Half of the black people I have posed this question to are angry, and the other half are sad. They all seem to agree on one fact: that the hand of reconciliation has been spat on. My friend the poet has an interesting take on the question of racial harmony. Friendly relations between races, according to my friend, are not necessary. What is required is the enforcement of equality in all spheres of society. If you do this with vigilance and commitment, he says - and only then - you might find, to your surprise, that some friendship does, indeed, result. (p. 9-10) 
Friendship as friendly relations between individuals, the character of the novel emphasises, is a nice but irrelevant thing in the face of structural injustice. Friendship as (often uncomfortable) intimacy and proximity with the other, on the other hand, can be a road towards conscientisation about the structural realities in one world. Such proximity does not indicate feeling good or even loved but rather feeling - or being pushed to feel - the suffering and joys of the other, and sharing those of oneself.

\section{Seeking radical friendship in inner- city Johannesburg}

It would, of course, be naïve to think that such real and intimate relationships across class, race, gender, sexuality and other boundaries are easy to enact in a local faith community. However, the potential for creating such spaces is available to leaders at the different levels of local faith communities, especially in cities like Johannesburg that are characterised by both social distance and physical closeness between different groups of structurally privileged and marginalised persons.

At the CMM, the journey of the Teen Church in 2009 is an example of the potential embedded in fostering proximity with the other. Young members of the CMM attended the Teen Church during the morning service on Sundays. In 2009 their teacher decided to invite the Zimbabwean youth who stayed at the CMM to join the group, and a number of these young people did begin to sit in the classes.

Whilst the South African youth came to the church for worship, the Zimbabweans were asylum seekers who slept and schooled in the overcrowded church. As noted above, the relationship between the two groups at the church at large was not warm. Likewise, according to the young South Africans that I spoke with, the original Teen Church class was initially not excited about the new development: 'I didn't like the idea at all. I was not open to it at all', Olwethu said. 'They're dirty, they're around me, they're in my space ... There wasn't even a certain, a valid reason [for me not to want them in the class]. It was just being petty' (quoted in Hankela 2014a:332-333) ${ }^{5}$. I was also told that some young people stopped coming to the Teen Church.

The teacher had been a member at the CMM for a long time and was supportive of Verryn's liberationist vision and the Refugee Ministry. Her primary reason to invite the Zimbabwean youth to join the class was not to achieve integration at the church, but rather it was in line with her understanding of God's nature: God does not love a citizen more than a foreign national, and worship should be visible in one's lifestyle and in how one treats the next person.

In the process, according to the narration of the young South Africans, the attitudes of some of the local young people changed from looking down on the Zimbabweans to

5.Interview conducted with Olwethu (name changed) by author in Johannesburg on 19 July 2009. realising that 'they' are human beings just like 'us' and that we can learn from them. These changes were, at least partly, possible due to the teacher's insistence on representatives of the two groups to literally sit next to each other and listen to one another, and also by an atmosphere where, according to Mxolisi, the young people were not 'limited in [their] thinking', but rather the teacher was open to learning from them too (quoted in Hankela 2014a:339) ${ }^{6} .7$

The transformation that took place in the Teen Church was not complete or painless. Here I have only highlighted a few aspects of the developments in 2009 in order to illuminate the opportunity that physical proximity provides for faith communities to foster encounters, pose difficult questions and encourage radical friendship between persons from different walks of structural life. The realisations by individuals and groups could then be harnessed towards a collective journey of thinking and talking about society, whilst the community itself could start to reflect an alternative society.

\section{Concluding remarks}

It is often said that South Africa is a microcosm of the world. In Johannesburg, Alexandra Township and the economic hub of Sandton are physically right next to each other, only the M1 highway separating the two spaces. Socio-economically they are distant realities. In both areas Christians gather Sunday after Sunday to worship the seemingly same God and the Jesus of Nazareth. Yet the historical Jesus was a revolutionary, a colonised subject of Rome, who spoke against the powers; rather than 'a meek and mild savior who did not disrupt the status quo' or 'a colonial Christ who sided with the powerful and blessed imperial realities' (DeYoung \& Boesak 2012:49). The revolutionary would not sit neatly in a faith community that wishes to keep the social, political and economic structures outside the core of faith or religion, or that remains silent in the face of dehumanising structures.

The depth of the gap, which the M1 highway symbolises, between privilege and marginalisation and between people who share in these locations calls for an alternative faith community, as a matter of urgency. Hence I argued for the liberationist discourse to make the faith community a conscious centre of debate and praxis, in order for the discourse to become tangible in society. The rebellion that Petrella calls for would then indeed be directed against liberation theology as a kind of writing, as a field of production, and harnessed instead towards returning to the roots of the tradition. Attention would now be on calling the faith community as a community to conversion. This is exactly why liberation theology qua theology still has a mission: the mission is to give Christian communities a reason to take liberation dead seriously. In South Africa, for instance, this is no small mission as it targets three quarters of the population.

6.Interview conducted with Mxolisi (name changed) by author in Johannesburg on 26 July 2009

7.The remarks made on the Teen Church are based on Hankela (2014a:327-344) 
In the latter half of the article I began to imagine what it would mean to do this, and engaged with some of the recent liberationist writings in order to seek for building blocks for liberationist faith communities, in particular in spaces like Johannesburg. Critical deconstruction and radical friendship are notions geared towards ensuring agency for each person in community, regardless of one's social location. Hence they are also directed towards placing responsibility on each person in the face of structural injustice. Yet they are but a starting point for reflection, or praxis, that is centred on faith communities.

\section{Acknowledgements}

I would like to thank the editors of this special issue, Stephan de Beer and Ignatius Swart; and J.N.J. Klippies Kritzinger; and the anonymous reviewers designated by HTS for their comments on the previous drafts of this article. I also remain grateful to several people at the Central Methodist Mission (CMM) for the insight I gained there during my doctoral studies (some results of which I reference in this article), and in particular, to Rev. Dr Paul Verryn for allowing me access to the CMM as well as to his own theological thinking.

\section{Competing interests}

The author declares that she has no financial or personal relationship(s) that may have inappropriately influenced her in writing this article.

\section{References}

Boesak, A., 2012, 'Reconciliation, risk, and resistance: The story of Rizpah', in A. Boesak \& C. DeYoung (eds.), Radical reconciliation: Beyond political pietism and Christian quietism, pp. 25-39, Orbis, Maryknoll.

Buffel, O., 2010, 'Black theology and the Black masses: The need of an organic relationship between Black theology and the Black masses', Scriptura 105, 470480. http://dx.doi.org/10.7833/105-0-166

Chipkin, I. \& Leatt, A., 2011, 'Religion and revival in post-apartheid South Africa', FOCUS 62, 39-46.

Clarke, G. \& Jennings, M. (eds.), 2008, Development, civil society and faith-based organizations: Bridging the sacred and the secular, Palgrave Macmillan, New York.

Cone, J., 1997, Black theology and Black power, Orbis, Maryknoll.

Cone, J., 2013, The cross and the lynching tree, Orbis, Maryknoll.

Cooper, T., 2013, 'Introduction', in T. Cooper (ed.), The reemergence of liberation theologies: Models for the twenty-first century, pp. 1-9, Palgrave Macmillan, New York. http://dx.doi.org/10.1057/9781137311825.0003

DeYoung, C., 2012, 'Reconciliation in diverse congregations: Restoring the beloved community', in A. Boesak \& C. DeYoung (eds.), Radical reconciliation: Beyond political pietism and Christian quietism, pp. 77-91, Orbis, Maryknoll.

DeYoung, C. \& Boesak, A., 2012, 'Jesus the radical reconciler: Two takes, one perspective', in A. Boesak \& C. DeYoung (eds.), Radical reconciliation: Beyond political pietism and Christian quietism, pp. 43-55, Orbis, Maryknoll.

Du Plessis, D., 2014, 'A critical reflection on urban spatial planning practices and outcomes in post-apartheid South Africa', Urban Forum 25, 69-88.

Farmer, P., 2013a, 'A doctor's tribute to Gustavo Gutiérrez', in M. Griffin \& J. Weiss Block (eds.), In the company of the poor: Conversations with Dr Paul Farmer and Fr. Gustavo Gutiérrez, pp. 15-25, Orbis, Maryknoll.

Farmer, P., 2013b, 'Conversion in the time of Cholera: A reflection on structura violence and social change', in M. Griffin \& J. Weiss Block (eds.), In the company of the poor: Conversations with Dr Paul Farmer and Fr. Gustavo Gutiérrez, pp. 95-145, Orbis, Maryknoll.

Freire, P., 2000, Pedagogy of the oppressed, Continuum, New York.
Gutiérrez, G., 2013a, 'Saying and showing to the poor: "God loves you"', in M. Griffin \& J. Weiss Block (eds.), In the company of the poor: Conversations with Dr Paul Farmer and Fr. Gustavo Gutiérrez, pp. 27-34, Orbis, Maryknoll.

Gutiérrez, G., 2013b, 'Conversion: A requirement for solidarity', in M. Griffin \& J. Weiss Block (eds.), In the company of the poor: Conversations with Dr Paul Farmer and Fr. Gustavo Gutiérrez, pp. 71-93, Orbis, Maryknoll.

Gutiérrez, G., 2013c, 'The option for the poor arises from faith in Christ', in M. Griffin \& J. Weiss Block (eds.), In the company of the poor: Conversations with Dr Paul Farmer and Fr. Gustavo Gutiérrez, pp. 147-159, Orbis, Maryknoll.

Hamann, C. \& Horn, A., 2014, 'Continuity or discontinuity? Evaluating the changing socio-spatial structure of the city of Tshwane, South Africa', Urban Forum, 05 April. http://www.dx.doi.org/10.1007/s12132-014-9231-7

Hankela, E., 2013, 'Rules of reciprocity and survival in negotiating Ubuntu at the Central Methodist Mission in Johannesburg', Journal of Theology for Southern Africa 147, 73-89.

Hankela, E., 2014a, Ubuntu, migration and ministry: Being human in a Johannesburg church, Brill, Leiden. http://dx.doi.org/10.1163/9789004274136

Hankela, E., 2014b, "'We're not liberated yet in South Africa": Liberation theology and the concept of humanity in inner-city Johannesburg', Religion and Theology 21 173-206. http://dx.doi.org/10.1163/15743012-02101005

Hlongwane, P., 2013, Jozi: A novel, UKZN Press, Scottsville.

Krige, S., 2008, 'Towards a coherent vision for faith-based development', Journal of Theology for Southern Africa 132, 16-37.

Landau, L., 2007, 'Discrimination and development? Immigration, urbanisation and sustainable livelihoods in Johannesburg', Development Southern Africa 24(1), 61-76. http://dx.doi.org/10.1080/03768350601165876

Le Bruyns, C., 2012, 'Religion and the economy? On public responsibility through prophetic intelligence, theology and solidarity', Journal of Theology for Southern Africa 142, 80-97.

Maluleke, T., 2000, 'Black and African theology after apartheid and after the Cold War: An emerging paradigm', Exchange 29(3), 193-212. http://dx.doi. Cold War: An emerging paradign
org/10.1163/157254300X00148

Medina, N., 2013, 'Rethinking liberation: Toward a Canadian Latin@ theology', in T. Cooper (ed.), The reemergence of liberation theologies: Models for the twenty-first century, pp. 77-87, Palgrave Macmillan, New York. http://dx.doi. twenty-first century, pp. 77-87, P
org/10.1057/9781137311825.0015

Mosala, I., 1989, Biblical hermeneutics and Black Theology, William B. Eerdmans Publishing Company, Grand Rapids.

Moyer, J., Sinclair, A. \& Spaling, H., 2012, 'Working for God and sustainability: The activities of faith-based organizations in Kenya', Voluntas 23, 959-992. http:// dx.doi.org/10.1007/s11266-011-9245-x

Motlhabi, M., 2009, 'Phases of Black Theology in South Africa: A historical overview', Theology and Religion 16(3/4), 162-180. http://dx.doi.org/10.1163/10230800 9X12561890523555

Murray, M., 2011, City of extremes: The spatial politics of Johannesburg, Duke University Press, Durham. http://dx.doi.org/10.1215/9780822391814

Oakly, N., 2004, 'Base Ecclesial communities and community ministry: Some Freirean points of comparison and difference', Political Theology 5(4), 447-465.

Oduyoye, M., 2001, Introducing African women's theology, Sheffield Academic Press, Sheffield.

Petrella, I., 2008, Beyond liberation theology: A polemic, SCM Press, London, Kindle edition.

Pityana, B., 1994, 'Black Theology', in J. de Gruchy \& C. Villa-Vicencio (eds.), Doing theology in context, pp. 173-183, David Phillip, Cape Town.

Sedibi, L., 1986, 'The dynamics of the Black Struggle and its implications for Black Theology', in I. Mosala \& B. Tlhagale (eds.), The unquestionable right to be free: Essays in Black Theology, pp. 1-36, Skotaville Publishers, Johannesburg.

Storey, P., 2004, And are we yet alive? Revisioning our Wesleyan heritage in the new southern Africa, Methodist Publishing House, Cape Town.

Valentín, B., 2013, 'Dialogic mediations: Reflections on the hopeful future of US liberation theology', in T. Cooper (ed.), The reemergence of liberation theologies: Models for the twenty-first century, pp. 49-56, Palgrave Macmillan, New York. Models for the twenty-first century, pp. 49-56,
$\mathrm{http} / / / \mathrm{dx}$.doi.org/10.1057/9781137311825.0011

Vellem, V., 2012, 'Interlocution and Black Theology of liberation in the 21st century: A reflection', Studia Historiae Ecclesiasticae 38(suppl.), 345-360.

Villa-Vicencio, C., 2014, The dangerous memory of the gospel \& South Africa Palestine and the papal visit to the Holy Land, viewed 20 May 2014, from http:// kairossouthernafrica.wordpress.com/2014/05/19/south-africa-palestine-andthe-papal-visit-to-the-holy-land-by-charles-villa-vicencio

Vuola, E., 2003, 'The option for the poor and the exclusion of women: The challenges of postmodernism and feminism to liberation theology', in J. Rieger (ed.), Opting for the margins: Postmodernity and liberation in Christian theology, pp. 105-126, Oxford University Press, Oxford. http://dx.doi.org/10.1093/019516119x.003.0006

Winkler, T., 2013, 'Why won't downtown Johannesburg "regenerate"? Reassessing Hillbrow as a case example', Urban Forum 24, 309-324. 